\title{
The genus Asterina and its anamorph on Elaeocarpus species in Southern Western ghats of peninsular India
}

\author{
V. B. Hosagoudar \\ Tropical Botanic Garden and Research Institute, Palode - 695562, Thiruvananthapuram (Kerala), INDIA \\ E-mail: vbhosagoudar@rediffmail.com
}

Abstract : The present study observed that the family Elaeocarpaceae comprises three genera: Elaeocarpus, Sloanea and Muntingia in India. Of these, Elaeocarpus munronii, E. serratus, E. tectorius and E. tuberculatus were found infected with Asterina gamsii, A. elaeocarpi var. ovalis, A. elaeocarpicola and Asterostomella elaeocarpi-serrati in the Southern Western Ghats of peninsular India. All these species are described and illustrated in detail.

Keywords : Fungi, Black mildews, Asterina, Elaeocarpus, Southern western ghats

\section{INTRODUCTION}

The family Elaeocarpaceae comprises three genera, namely, Elaeocarpus, Sloanea and Muntingia. The genus Sloanea is distributed in North and North-eastern states, while Muntingia is an introduced and cultivated ornamental plant for its profuse showy flowers. The genus Elaeocarpus comprises about 200 species, and of which 29 are represented in India. These are confined to north eastern and southern India, while few are in Andaman and Nicobar Islands. They prefer warm humid climate and occur at an altitude between 200 to $2000 \mathrm{~m}$. About twelve species are known from the southern Western Ghats (Murti, 1993) and of which, Elaeocarpus munronii (Wight) Masters, Elaeocarpus serratus L., Elaeocarpus tectorius (Lour.) Poiret and Elaeocarpus tuberculatus Roxb. were found infected with Asterina species.

The genus Asterina belongs to the family Asterinaceae of the order Asterinales. It is characterized by an ectophytic, septate, brown, branched, appressoriate mycelium. Ascoma is flattened with radiating cells is called thyriothecium. Thyriothecium orbicular, flattened, with upper radiating cells, fimbriate to crenate at the margin, dehisce stellately at the centre. Asci globose, bitunicate, mostly octosporous, persistent. Ascospores brown, two celled.

\section{Type: A. melastomatis Lev.}

The genus Lembosia is allied to Asterina, belongs to the family Lembosiaceae but differs from it in having ellipsoidal to elongated thyriothecia which splits vertically (in contrast to stellately) at the centre (Hosagoudar et al., 2001).

Asterinaceous fungi are obligate biotrophs that cause least apparent damage to the host plants but bring biochemical changes as is evidenced in the case of Santalum album infected with Asterina congesta Cooke (Hosagoudar et al., 1997). These biochemical changes, which occur in the plants, may be of immense use as in the case of 'ergot' caused by Claviceps purpurea Cooke. Keeping this in view, the present study has been undertaken with the taxonomic aspect of the Asterina spp. infecting the species of the host genus Elaeocarpus

\section{KEY TO THE ASTERINA SPECIES}

1.Present only in anamorph state ... Asterostomella elaeocarpi-serrulati

1. Present in teleomorph state ...2

2. Appressoria cylindrical, straight, flexuous, uncinate, often forked

2. Appressoria not so $\quad \ldots \quad$... Asterina elaeocarpicola

3. Appressoria cylindrical, tubular, elongated, rounded at the apex $\quad$...Asterina elaeocarpi var. ovalis

3. Appressoria ovate to cylindrical, entire, rounded at the tip ...

Asterina gamsii

\section{Enumeration of the species}

1.Asterina gamsii Hosagoudar (2005) (Fig.1).

Colonies epiphyllous, dense, velvety, up to $3 \mathrm{~mm}$ in diameter and cover an entire upper portion of the leaves. Hyphae straight to substraight, branching irregular at acute angles, loosely to closely reticulate, cells $16-23 \times 4-$ $7 \mu \mathrm{m}$. Appressoria alternate, unilateral and about $20 \%$ opposite to subopposite, mostly straight, subantrorse to rarely retrorse, ovate to cylindrical, entire, rounded at the apex, $8-13 \times 6-8 \mu \mathrm{m}$. Thyriothecia closely scattered, orbicular, 


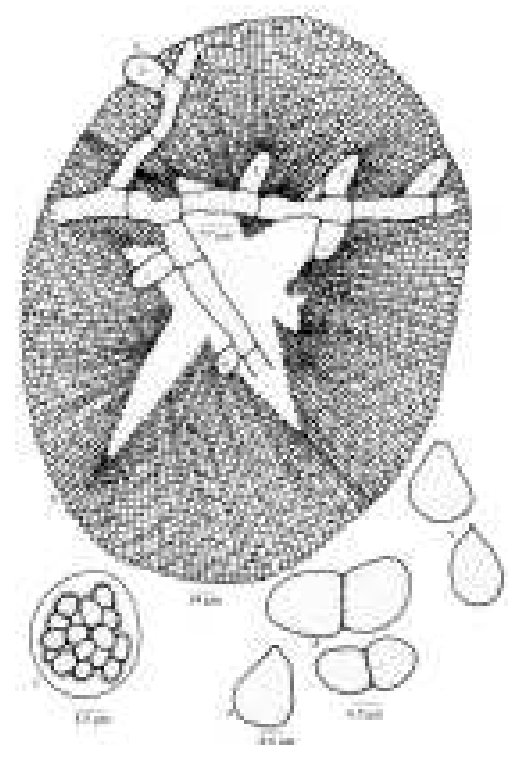

Fig. 1. Asterina gamsii Hosagoudar a.Appressoriate mycelium, b. Thyriothecium, c. Ascus, d. Ascospores, e. Pycnothyriospores

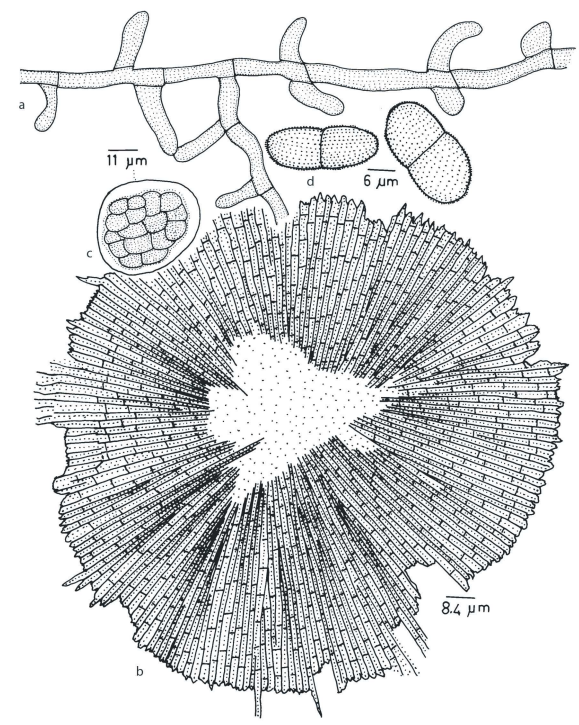

Fig. 2. Asterina elaeocarpi Sydow var. ovalis Kar and Maity a. Appressoriate mycelium, b. Thyriothecium, c. Ascus, d. Ascospores

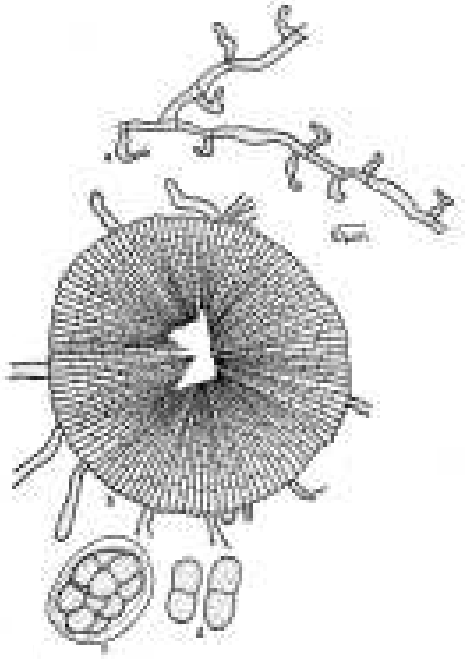

Fig. 3. Asterina elaeocarpicola Hansford a. Appressoriate mycelium, b. Thyriothecium, c. Ascus, d. Ascospores

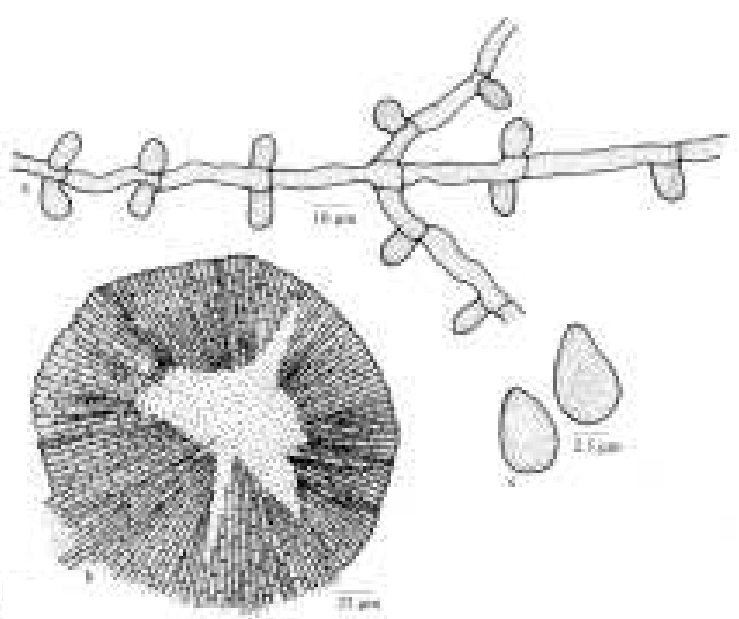

Fig. 4. Asterostomella elaeocarpi-serrati Hosagoudar a. Appressoriate mycelium, b. Pycnothyrium, c. Pycnothyriospores

up to $300 \mu \mathrm{m}$ in diameter, stellately dehisced at the centre, crenate to fimbriate at the margin, fringed hyphae flexuous; asci few to many, globose, octosporous, up to $38 \mu \mathrm{m}$ in diam.; ascospores oblong, brown, uniseptate, constricted at the septum, 32-36 x 11-18 $\mu \mathrm{m}$, wall smooth. Pycnothyria similar to thyriothecia, smaller; pycnothyriospores pyriform, apiculate, brown, $22-26 \times 16-18 \mu \mathrm{m}$.

Materials examined: On leaves of Elaeocarpus tectorius (Lour.) Poir (E. oblongus auct. non Gaertn.), Sairandhri, Silent valley, Palghat, Kerala, Dec. 13, 2003, V.B. Hosagoudar and al TBGT 1502, HCIO 45753; Chempatty, Silent Valley, Palghat, Kerala, Dec. 14, 2003, 
V.B. Hosagoudar \& al TBGT 1900, HCIO 46137; Moozhiyar forest, Pathanamthitta, Kerala, Dec. 14, 2004, V.B. Hosagoudar \& al TBGT 1861, HCIO 46098.

There are five species, namely, Asterina borneensis Hansf., A. elaeocarpi Sydow, A. elaeocarpi Sydow var. ovalis Kar \& Ghosh, A. elaeocarpicola Hansf. and A. elaeocarpi-kobenmochi Yamam., known on the members of the family Elaeocarpaceae (Hosagoudar and Abraham, 2000). Asterina gamsii differs from A. elaeocarpicola and $A$. borneensis in having octosporous asci and straight appressoria (Hansford, 1954). It differs from A. elaeocarpi in having opposite appressoria and larger ascospores. It also differs from A. elaeocarpi var. ovalis in having ovate appressoria in contrast to longer and cylindrical ones (Kar and Ghosh, 1986). In A. elaeocarpi-kobanmochi appressoria are predominantly opposite and oblong and ascospores are smaller (Yamamoto, 1957).

2. Asterina elaeocarpi Sydow var. ovalis Kar and Maity (1986); Hosagoudar, Balakrishnan and Goos (1996) (Fig.2).

Colonies epiphyllous thin to subdense, up to $2 \mathrm{~mm}$ in diameter, confluent and cover the entire upper surface of the leaves. Hyphae straight to substraight, branching alternate to opposite at acute to wide angles, loosely reticulate, cells 8-13 x 3-4 $\mu \mathrm{m}$. Appressoria alternate, opposite to subopposite, ovate to oblong, long, elongated, unicellular, entire, 4-24 x 4-5 $\mu \mathrm{m}$. Thyriothecia scattered to connate, orbicular, up to $160 \mu \mathrm{m}$ in diameter, stellately dehisced at the centre, crenate to fimbriate at the margin, fringed hyphae flexuous; asci few to many, globose to ovate, octosporous, 35-45 $\mu \mathrm{m}$ in diameter; ascospores oblong, conglobate, deep brown, uniseptate, constricted at the septum, 22-24 x 9-13 $\mu \mathrm{m}$, wall coarsely echinulate.

Materials examined: On leaves of Elaeocarpus tuberculatus Roxb., Karingundru, Valparai, Anamalai, Coimbatore, Tamil Nadu, Dec. 26, 1990, V.B. Hosagoudar HCIO 30961; Athirumala, Neyyar Wildlife Sanctuary, Thiruvananthapuram, Kerala, March 26, 1996, V.B.Hosagoudar TBGT 48, HCIO 42176; Periya, Wyanad, Kerala, Feb. 6, 2002, M. Kamarudeen TBGT 622, HCIO 44297; Dec. 27, 2002, M. Kamarudeen \& P.A. Jose TBGT 1024, HCIO 44787; Sairandhri, Silent valley, Palghat, Kerala, Dec. 13, 2003, V.B. Hosagoudar \& al TBGT 1521, HCIO 45772; Tirunelly, Wyanad, Kerala, May 20, 2002, S. Shiburaj TBGT 920, HCIO 44638; Attayar, Thiruvananthapuram, Kerala, March 19, 1997, V.B.HosagoudarTBGT 485, HCIO 44077; Moozhiyar forest, Pathanamthitta, Kerala, Dec. 14, 2004, V.B. Hosagoudar \& al TBGT 1644, HCIO 46232; Kakki dam, Moozhiyar forest, Pathanamthitta, Kerala, Dec. 14, 2004, V.B. Hosagoudar TBGT 1750, HCIO 45986; Elaeocarpus sp., Shendurney, Kollam, Kerala, Jan. 14, 2003, V.B. Hosagoudar TBGT 41, HCIO 44854; Sairandhri, Silent valley, Palghat, Kerala, Dec. 13, 2003, V.B.
Hosagoudar \& al TBGT 1825, HCIO 46062.

This taxon is distinct from other Asterina species reported on the members of the host genus Elaeocarpus in having cylindrical to tubular, short to elongated, unicellular appressoria which are broadly rounded at the tip.

This taxon is common on Elaeocarpus tuberculatus in the Western Ghats region of Peninsular India.

3. Asterina elaeocarpicola Hansford (1954); Hosagoudar and Goos (1996) (Fig.3).

Colonies amphigenous, mostly hypophyllous, subdense, up to $3 \mathrm{~mm}$ in diameter, confluent and cover the entire lower surface of the leaves. Hyphae sinuous to crooked, branching irregular at acute angles, loosely reticulate, cells 15-19 x 3-5 $\mu \mathrm{m}$. Appressoria mostly unicellular, mostly alternate, rarely opposite, cylindrical, straight, flexuous, mostly irregularly uncinate, rarely forked, $9-19 \times 3-5 \mu \mathrm{m}$. Thyriothecia closely scattered and often connate, orbicular, up to $186 \mu \mathrm{m}$ in diameter, margin crenate, rarely fimbriate, dehiscing stellately at the center; asci many, octosporous, globose, 40-44 $\mu \mathrm{m}$ in diameter; ascospores conglobate, brown, 1 - septate, $24-28$ x 9-13 $\mu \mathrm{m}$.

Materials examined: On leaves of Elaeocarpus munronii (Wight) Masters, Kakachi forest, Tirunelveli, Tamil Nadu, Feb.21, 1994, V.B. Hosagoudar HCIO 41630; Moozhiyar forest, Pathanamthitta, Kerala, Dec. 14, 2004, V.B. Hosagoudar \& al. TBGT 1810, HCIO 46047; Pachakanam, Moozhiyar forest, Pathanamthitta, Kerala, Dec. 15, 2004, V.B. Hosagoudar \& al. TBGT 1808, HCIO 46045; Elaeocarpus sp., Kakki dam, Moozhiyar forest, Pathanamthitta, Kerala, Dec. 15, 2004, V.B.Hosagoudar \& al TBGT 1934, HCIO 46288.

Curved to uncinate appressoria are the characters of this species.

4. Asterostomella elaeocarpi-serrati Hosagoudar in Hosagoudar, Biju and Anu Appaih (2006) (Fig. 4).

Colonies amphigenous, dense, up to $1 \mathrm{~mm}$ in diameter, rarely confluent. Hyphae straight to flexuous, branching mostly opposite at acute angles, loosely to closely reticulate, cells 8-24 x 5-7 $\mu \mathrm{m}$. Appressoria alternate, about $30 \%$ opposite, unicellular, conoid, ovate, entire, straight, attenuated and broadly rounded at the apex, 8-13 x 6-8 $\mu \mathrm{m}$. Pycnothyria scattered, orbicular, up to $258 \mu \mathrm{m}$ in diameter, stellately dehisced at the centre, margin crenate; pycnothyriospores pyriform, brown, 20-26 x 19-21 $\mu \mathrm{m}$, wall smooth.

Materials examined: On leaves of Elaeocarpus serratus L., Abbe falls, Madikeri, Coorg, Karnataka, Nov. 11, 2003, V.B. Hosagoudar \& al. HCIO 45817, TBGT 1567.

This is an anamorph of the genus Asterina and is close to A. borneensis Hansf. in having smaller and alternate to opposite appressoria. However, differs from it in having conoid but $30 \%$ opposite appressoria (Hansford, 1954). 


\section{ACKNOWLEDGEMENTS}

Thanks are due to the Director, TBGRI, Palode for the facilities. Dr. Ganesan, ATREE, Bangalore is acknowledged for his hospitality during the field collection tour to Upper Godayar.

\section{REFERENCES}

Hansford, C.G. (1954). Some Microthyriales and other fungi from Indonesia. Reinwardtia 3: 113-144.

Hosagoudar, V.B. (2005). Studies on foliicolous fungi - XIX. Indian Phytopathol. 58: 194-204.

Hosagoudar, V.B. and Abraham, T.K. (2000). A list of Asterina Lev. species based on the literature. J. Econ. Taxon. Bot. 24 : 557-587.

Hosagoudar, V.B., Abraham, T.K. and Biju, C.K. (2001). Reevaluation of the family Asterinaceae. J. Mycopathol. Res. 39: 61-63.

Hosagouder, V.B., Balakrishan, N. P. and Goos, R.D. (1996).
Some Asterina species from southern India. Mycotaxon, 59: 167-187.

Hosagoudar, V.B., Biju, H. and Anu Appaiah, K.A. (2006). Studies on foliicolous fungi - XX. Microfungi of Coorg, Karnataka. J. Mycopathol. Res. 44: 1-25.

Hosagoudar, V.B. and Goos, R.D. (1996). Some foliicolous fungi from southern India. Mycotaxon 59: 149-166.

Hosagoudar, V.B., Krishnan, P.N. and Abraham, T.K. (1997). Biochemical changes in the Sandal tree infected with Asterina congesta Cooke. New Botanist 24: 27-32.

Kar, A.K. and Ghosh, S.N. (1986). New Asterina species from West Bengal. Indian Phytopathol. 39: 204-220.

Kar, A.K. and Maity, M.K. (1986). New Asterina species from West Bengal. Indian Phytopathol. 39: 204-220.

Murti, S.K. (1993). Elaeocarpaceae. Pp. 528-571. In: B.D. Sharma and M. Sanjappa (eds.). Flora of India. Botanical Survey of India, Calcutta.

Yamamoto, W. (1957). The Formosan species of the Microthyriaceae - II. Sci. Rep. Hyogo Univ. Agric., Agric. Biol. Ser. 3: 23-31. 